\title{
PERSONAL NAMES AND IDENTITY IN LITERARY CONTEXTS
}

\author{
BENEDICTA WINDT-VAL \\ University of Oslo
}

ABSTRACT

This article is an attempt to show the close connection between a person's given name and their feeling of identity and self. This connection is very important - it has even been stated that the parents' choice of name for their child will have an influence on the development of the personality of the child. Moreover, personal names and place names are some of the most important tools of the author in the creation of credible characters placed in a literary universe that gives the impression of being authentic. Many authors from different countries have related their view of the significance of names and naming, not only as a source of information for the reader, but also as an important part of making the characters real to the authors themselves during the process of writing.

\section{[1] INTRODUCTION}

I would like to start this piece with an extract from a poem by the Swedish poet Gunnar Ekelöf (1907-1968), because it states very clearly the connection between names and identity:

Och människans lott står oföränderligt fast

men du har hunnit ännu ett steg på ditt önskandes byggnad:

Ännu en önskan av alla de tänkbara tusen och tusen

har blivit dig möjlig, nödvändig, viss och slutligen faktum,

liksom du själv som också var önskan från början,

liksom det magiska namnet föräldrarna gett dig

att skydda från mörker och jaglöshet,

att skilja just dig från tusen liknande och nästan lika.

Och ändå är du i botten så namnlös som natten och mörkret:

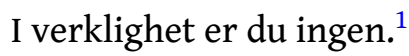

[1] Gunnar Ekelöf, “Tag och skriv”, from the collection Färjesång (Ekelöf 1941). 
Translated into English the poem goes like this:

And the lot of man stands unalterably fast

but already you have taken another step in the structure built by wishes:

Another wish in the thinkable thousands and thousands

has become possible to you, necessary, certain, and finally fact,

just as you yourself who were also a wish from the start,

just like the magic name your parents gave you

to shelter you from the dark and I-less state,

to separate you from the thousands alike and almost alike.

And still under it all you are as nameless as the night and the darkness:

In reality you are no one. ${ }^{2}$

The way I read Ekelöf, he is alluding to the difficult and complex relationship between human beings and their own sense of identity - an identity which is closely and intimately related to the names and name-like designations that are given to us by ourselves or by the people surrounding us.

I would like to illustrate this point by relating an incident that took place many years ago, when I was a private tutor for students in high school, helping them to improve their marks in German and English. One day I was approached by the parents of a seventeen-year-old girl who seemed unable to learn German. When I met her, I found she was bright, intelligent - and extremely angry and disconsolate. I could not teach her anything until I had discovered the reason for her agitation. It turned out that her teacher at school had refused to use the students' names in class - he always addressed them only by the number they had been given on his list of students in class. This girl felt that the teacher had stripped her of identity and personality and made her into some kind of robot-like person, which naturally made her feel desolate and angry. As soon as she felt sure that I respected her identity and acknowledged her integrity as a person, she had no problems learning German. And she, in return, taught me a lot of the close connection between personal names and identity.

\section{[2] LANGUAGE, CULTURE AND IDENTITY}

Language is an organism developing through the interaction between people. It is alive within each and every person, not only as a down-to-earth and useful means

[2] Gunnar Ekelöf, 'Write It Down', in Songs of Something Else: Selected Poems of Gunnar Ekelöf, translated by Leonard Nathan and James Larson (Princeton: Princeton University Press, 1982), p. 39. 
of communication with the surroundings, but also as an inner tool constituting an essential part of the contents of our consciousness. Language is our most important utensil in our mental organization of experiences and memories, in problem solving, in the very structuralizing of our lives. It is an indispensible instrument in our attempts to interpret our surroundings, when we make associations and when we try to express our feelings.

Language also has an important function as a carrier of culture and identity. Through the words we choose when talking, we create the picture of ourselves that we want others to see. Human nature is polyphonic - our so-called personality consists of many different aspects which, when added up, constitute what we term "our identity". What aspects of ourselves we choose to present at any given moment will depend on whether the people surrounding us are family members, schoolmates, fellow sportspeople, close friends, acquaintances, a girlor boyfriend, our boss, colleagues or subordinates. The choice we make will often manifest itself through the name by which we choose to present ourselves to the surroundings. Do we include our title, given that we have one? Do we state our given name, our surname, or both? Maybe we choose to state a nickname or a pet name instead of the name our parents have decided for us. This may seem like a casual choice, or maybe just a matter of habit, but the fact is that the way we use our name constitutes an important part of the impression we want other people to form of ourselves.

Our personal perception of identity does not represent a stable unity. It changes as we gain experience, along with our personal growth. The American psychologist Gordon Allport has done ground-breaking work on the study of the personality. According to his theories our given name is the focal point around which we organize our personality, which is why it is of such crucial importance to us (Allport 1961). Another American psychologist, Kenneth L. Dion, suggests that the parents' choice of name for their child will have an influence on the development of the personality of the child (Dion 1983, 247). This assertion really gives grounds for reflection. If he is right, it might mean that I would be a totally different person today if my parents had named me Alexandra or Victoria instead of Benedicta...

\section{[3] NATION BUILDing AND CHOICE OF NAME}

The connection between names and identity does not only affect people. Names and naming also constitute an important part of the work of the building of a nation. This becomes quite evident if we take a look at the history of Norway during the period following the dissolution of the union with Denmark in 1814. The Norwegian people gained a new feeling of freedom and independence which provoked a strong wave of National Romanticism, and this, among many other things, also called forth a strong agitation to bring back the Old Norse and Nordic names and 
put them to use instead of imported, foreign names. This revival of the so called national names has later become known as the Nordic Name Renaissance. It is a well-known fact that quite a lot of the names that flourished during this period, had been found earlier in literature, but had never been in actual use as given names. As a consequence of National Romanticism they were now derived from Old Norse literature such as the sagas written by the Icelandic historian and poet Snorri Sturluson, and adopted as "genuine Norwegian names". Thus literature was of great importance to the supply of personal names during this period, and the use of the old Norse names contributed to the construction of national pride and a common feeling of identity.

This influence also worked in the opposite direction, however. The Nordic Name Renaissance became a source of inspiration for the choices of names in literature. This of course is manifest first and foremost in the literary works of Bjørnstjerne Bjørnson and Henrik Ibsen, who both took a very active part in the project of nation building, but it is also evident in the works of e.g. Johan Falkberget. The Norwegian researcher Ola Stemshaug has described the early works of Falkberget as an example of "programmatic and stereotyped use of names regarded as representative of the National Romanticism" (Stemshaug 1981, $17 \mathrm{f.}$ ). Both Ibsen and Bjørnson were strongly influenced by National Romanticism and centred their works on national topics. Ibsen wrote national dramas and chose Nordic and Norse names for his characters, e.g. Solveig and Åse, Einar, Kåre and Sigurd. Bjørnson's peasant tales drew the readers' attention to names like Øyvind, Arne, Ingrid, Synnøve og Torbjørn. The old Nordic names like Harald, Håkon and Sverre also play a significant part in the Norwegian national anthem "Ja, vi elsker dette landet", written by Bjørnson in 1859. ${ }^{3}$

The Norwegian Nobel laureate Sigrid Undset couldn't resist the temptation to make fun of the most bizarre effects of the Nordic Name Renaissance. In her novel Ida Elisabeth (1932) she presents a family of brothers and sisters with names like Frithjof, Geirmund, Herjulf, Jarngerd and Vikarr. Their parents mostly wear jackets knitted in Norwegian lice pattern, and their father plays a Hardanger fiddle.

Naturally this wave of Nordic and Norse names did not arouse the same amount of excitement among all Norwegian authors. Knut Hamsun disapproved of it even in his own private life. When he and his wife Marie were discussing which name to choose for their firstborn son, she wanted to call him Tore, and Hamsun answered her in a letter dated March $16^{\text {th }} 1912$ :

[3] The names included in the national anthem are not only names or fictional characters but refer to major figures of Norwegian history. 
Mærkelig; jeg har selv tænkt på Tore. [...] Per maa vi ialfald ikke kline paa ham, der er en hel Generation nu med Per og Aase og Ola og slikt Norgesmesterskap. ${ }^{4}$

Obviously Hamsun was not aware of the fact that also Tore was among the Norse names gaining in popularity during the Name Renaissance. Had he known this, he would probably have given his son another name.

Naturally the interaction between literature and "real life" is not limited to the period of Norwegian National Romanticism. There are innumerable examples of children being named after literary characters from the favourite novels of their parents. Literary names are taken from books and made part of the reservoir of names in actual use. The Ossian cycle of poems put together by James Macpherson around 1760 - who incidentally played an important role in the reclaiming of Gaelic culture and the construction of Scottish national feeling - spread like a wildfire all over Europe, creating a new fashion of names like Selma and Minona. The tale of Napoleon as the godfather of the only son of one of his generals, a certain Jean-Baptiste Bernadotte, is widely known. Napoleon decided to name the child Oscar, a name originating from the Ossian cycle of poems. This little Oscar later became king of Sweden and Norway.

\section{[4] LITERARY INFLUENCE ON NAMES CHOICE}

Even in our modern times, literary models have a great power of influence on the names that parents choose for their children. The Swedish author Astrid Lindgren has been a great source of inspiration for some recently popular names, in Sweden as well as in Scandinavia generally. The frequent use of the names Ronja, Birk, Emil and Ida has been inspired by her lively and likeable gallery of characters. The problem is of course that this kind of naming after literary characters not always brings great joy to the persons bearing the literary names. Sigrid Undset gives an example of this in her novel Den brennende busk (1930), where one of the female characters names her daughter Sunlife after the heroine of an "enchanting" American novel. When her daughter gets old enough to comment on her mother's choice of name, the judgment is short and scant: "Sunlife, det er da ikke noget navn igrunnen" - "Sunlife is not a real name" (my translation). ${ }^{5}$ It is easy to understand why she always refers to herself as Synne, which will by most people be interpreted as short for the traditional name Synnove.

Names have many different functions in real life, and all of these can be transferred to literature. The main condition for the reader to empathize fully with a

\footnotetext{
[4] Funny; I have also been thinking of Tore. [...] At any rate we mustn't call him Per, there's a whole generation now of Per and Aase and Ola and other names representing all kinds of Norwegian Championship." (My translation). (Hamsun 1988, 547).

[5] Undset: Den brennende busk, p. 262.
} 
literary work is that he or she is able to identify with the characters of the novel, their personality and actions. Personal names and place names are some of the most important tools of the author in the creation of credible characters placed in a literary universe that gives the impression of being authentic. The names in the novel generally will convey important information on many different aspects of the persons - family history, social setting, environment, self-image, personal ambitions, social status, and relationships between the characters. The list is more or less never-ending.

\section{[5] THE LITERARY UNIVERSE}

A literary universe is a well-suited starting point for a study of the process of naming and the motives behind it, especially when founded in the psychological realistic and/or the historic novelistic tradition. The French literary theorist Michel Grimaud characterized the process of naming and the use of names as "a deeply social, psychological, and linguistic act" (Grimaud 1989, 19). The social aspect is twofold. Firstly the choice of names and name fashions has mostly been influenced by social belonging, and secondly there are many rules restricting our way of addressing or referring to other people. The psychological function is related to emotions. Names and other terms of address often serve as a means of expressing feelings, and they can run the whole gamut from love to hatred. The linguistic function is relevant because names have different stylistic values and normative functions in different languages and within different geographical areas. In addition to these three aspects mentioned by Grimaud, there is also a historical element showing name fashions and name traditions throughout the ages.

Even Aristotle emphasized the importance of names in literature. In about 300 years B.C. he stated in his textbook on the art of poetry, Poetics, part IX:

[...] poetry tends to express the universal [...]. By the universal I mean how a person of a certain type on occasion speak or act, according to the law of probability or necessity; and it is this universality at which poetry aims in the names she attaches to the personages. [...] the poet first constructs the plot on the lines of probability, and then inserts characteristic names. ${ }^{6}$

The satirists and comedians of antiquity had no need for names as a tool for describing the individual personality of their characters, as this feature had already been established in advance. The characters in the ancient comedies were mostly a set of fixed types appearing in a whole series of plays. They did not change or develop in any way from play to play, and thus their names were more

[6] The Internet Classics Archive: http://classics .mit.edu/Aristotle/poetics.1.1.html. 
like tags telling the audience what to expect from the characters and what role they had been given in the thematic structure of the play. This is also typical of Classicism, which was inspired by antiquity, exemplified for instance in the comedies written by Ludvig Holberg. The servants Henrik and Pernille appear in several in his plays, representing respectively foolishness and smartness, while other characters have not even been given proper names - they are presented only by their profession and thus are characterized by the qualities attributed to a doctor, a lawyer and so on. Even the Romantic movement developed a string of internationally known heroes and heroines, equipped with more or less fixed characteristics - dauntless vigour, irreparable loneliness and melancholy. Again the identity of the person is fixed to the archetype instead of a name. However, as soon as the dramas developed into a free form, the names of the characters obtained a far more important role as bearers of meaning and symbols of their identity.

No literary époque has presented the author with greater challenges or possibilities than Realism. Realist authors based their writing on depictions of everyday banal activities and experiences from all classes of society, including the lower classes, without any romantic idealization or dramatization. Their aim was to give a faithful representation of reality, and thus, if they wanted to make personal names meaningful and relevant to the features and thematic function of their characters, they also had to make sure that they were in line with the actual use of names during the period of time they were describing.

\section{[6] FROM MARIA GRIPE TO SIGRID UNDSET}

Many authors from different countries have related their view of the significance of names and naming, not only as a source of information for the reader, but also as an important part of making the characters real to the authors themselves during the process of writing. Maria Gripe, a Swedish writer of books for children and young people, has given much thought to the connection between names and individual experience of identity and self. In her books one will often find a sort of mystery or game in relation to names and personal identity. Gripe has explained this as due to some unsettled feelings or points of view in her own perception of the relationship between people and names, and thus her characters interchange their names, hide their names or forget names. But Gripe emphasizes that this is not a conscious part of her plans for a book before she starts writing it, quite the opposite - it is something that her characters themselves insist on doing. Gripe's view of names is clearly stated by the heroine of Landet utanför (1967), a young princess:

Helst borde man också ha rätt att vara namnlös tills man själv finner sitt namn. Namn är ingenting att lättvändigt skänka hit och dit. Nam- 
net kan vara både för lätt och för tungt för en människa att bära. Och en boja är det alltid. Det kan utgöra en farlig lockelse eller bidra till at skapa självförakt. Det egna namnet kan bli till en myt som man faller offer for. Det kan splittra karaktären och bestämma ens öde. ${ }^{7}$

It is particularly interesting that even though this book contains several comments on names and the significance of names to each and every individual, not one of the characters has been given a name by the author.

In his dissertation on Agnar Mykle's novels on Ask Burlefot, Lasso Round the Moon (1954) ${ }^{8}$ and The Song of the Red Ruby (1956), Leif Johan Larsen states that Mykle found the topic of names and naming very fascinating, and that he often quoted the old Roman saying: "Nomen est omen" (Larsen 2001, 59). Mykle has chosen many unusual, almost sensational names in his works, names which - according to Larsen - "nærmest tvinger leseren til å lete etter en intensjonalitet bak navnebruken" . One of the most striking names is the name of the protagonist, Ask Burlefot, and even some of the characters in the novel find the name of the protagonist rather funny:

... han skrek Ask Burlefot, og det syntes de var et fornøyelig navn, og han var så hjertens enig med dem, han hadde gjennomgått meget i ungdommen på grunn av det navnet, men det var jo ikke han som hadde valgt det, men det kunne han ikke si; han måtte bare stå som en utstillingsdukke blant dem og hete Ask Burlefot og på det heftigste ønske at han hette Lars Olsen ${ }^{10}$.

The protagonist himself obviously feels that the identity given to him through his name is too conspicuous, too striking. Ask refers to old Nordic mythology, but also has a cross-reference to Norwegian folk tales and their recurrent figureAskeladden, and Burlefot is not an ordinary Norwegian surname. With a name like this it is impossible for him to hide in the crowd and try to be anonymous, and it is possible that the psychological explanation of Ask Burlefot's rather unpleasant behaviour through life is to be found in his name.

[7] "Preferably you should have the right to be nameless until you find your own name. Names are not something that should be given out light-handedly. A name can be too light, but also too heavy for a person to carry. And it will always be a shackle. It can be a dangerous temptation or it can create selfcontempt. Your own name can turn into a myth which you fall victim of. It can split your character and determine your fate." (Gripe 1967, 69). (My translation.)

[8] The Norwegian titles are Lasso rundt fru Luna and Sangen om den røde rubin.

[9] "in a way force the reader to look for an intentionality behind the use of names."

[10] "... he screamed Ask Burlefot, and they found this a very amusing name, and he agreed with all his heart, he had been through a lot in his youth because of this name, but it was not his own choice, though he could not say that, he just had to stand among them like a display dummy by the name of Ask Burlefot, while wishing intensely that his name had been Lars Olsen." (Mykle 1956, 121). (My translation.) 
Had his name been Lars Olsen, a very common name in Norway, he might not have felt that he had so much to prove to himself and others, and maybe he would then have been quite an ordinary and likeable young man instead of a selfish, insensitive rebel.

Philippe Hamon describes the function of names in realistic texts like this:

So the family forms a sort of "motivated", "transparent" (Saussure) derivational field, wherein the surnames play somewhat the role of a linguistic root or stem conveying a particular piece of information (hereditary facts, etc.) [...] while the first names act as a kind of inflection, offering complementary information [...], structures, then, functioning as a sort of "grammar" of characters [...]. (Hamon 1992, 167).

It is, however, not only the "official" names in a literary work that contribute to form the picture which the author wants to convey to the reader, describing the personal, social and geographical identity of the literary characters. Often we find that the characters have been given several names, a pet name or a nickname in addition to one or more Christian names, all of which are equally contextually relevant. Their social standing may be revealed through their way of introducing themselves, through their way of addressing other people, and through their way of referring to each other. This also applies to the mutual relations between the characters and the opinion they hold of each other and, not least important aspect, the opinion they hold of themselves. Pet names, nicknames and bynames can reveal a considerable amount about a person's position among equals and in his or her surroundings in general, and it is just as revealing when a person does not "feel at home" in their own name, but chooses instead to "hide" behind a pet name or use a name that actually does not belong to them.

Maria Gripe gives a touching example of this in her children's book Josefin (1961). ${ }^{11}$ The protagonist is a little girl by the name of Anna Grå. ${ }^{12}$ She feels much burdened by this grown-up, rather severe name; she feels that it makes demands of her that she cannot fulfil. Because of this she creates a new name for herself: Josefin Johandersson. This name provides her with an identity with which she can feel at home and comfortable. She finds that Josefin is a funny and quite special name, rather ideal for a girl who wants to play a prank from time to time.Johandersson is a combination of Johansson and Andersson, the two most common surnames she knows. With a name like this she becomes a little bit of both, special as well as ordinary, and she demands that everyone calls her this, even at school. But as Josefin develops and matures, she gains the strength to

[11] Josefin is the first book in a series of three: Josefin (1961), Hugo och Josefin (1962) and Hugo (1966). It seems significant that these books all use personal names as titles.

[12] Anna Grey. 
enter into her real identity again, and can drop the pseudonym she has been using as a mental hiding place.

Authors often make use of the strong connection between names and the feeling of personal identity as an element in their thematic structures. Maria Gripe has written a series of books about a small boy by the name of Elvis Karlsson (1972). He is named after his mother's big idol, Elvis Presley, and while growing up, he struggles hard to be allowed to develop his own personality and identity, and to get his mother to accept him as a person in his own right. Luckily he is a very strong boy, and he is able to handle the problems connected with his name. This is not the case in my next example.

The British "Queen of Crime", Agatha Christie, based the psychological explanation of the character of the murderer in The A.B.C. Murders (Christie 1936) on the influence of the name on the development of a person's identity and personality, which is exactly the same theory upheld by Kenneth Dion. The murderer is a small weakling of a man who has developed strong personality disorders due to the fact that he has never been able to honour the extreme expectations related to the name given to him by his parents: Alexander Bonaparte Cust. He describes his mother as "ambitious, enormously ambitious"13, and states that she "had this ridiculous notion that I would grow up and become an important man"14. His name, combined with his lack of ability to fulfil the ambitions of his mother, has given him extensive inferiority complexes, with the result that he is tricked into believing that he has committed several murders.

Even if you have been so fortunate as to have been given a name that does not make heavy demands on you, but instead a name that indicates positive qualities, a name that helps to create an encouraging picture of yourself, it is still possible for other people to manipulate your feeling of identity and self-view through their way of addressing you. This becomes quite obvious in a novel by the Norwegian author Ebba Haslund, Bare et lite sammenbrudd (Haslund 1975). ${ }^{15}$ The female protagonist was christened Beatrice. In Dante's Divine Comedy, Beatrice is immensely beautiful. She is a holy person and a symbol of serene dignity and love. Who could imagine a more inspiring ideal for a woman? But the husband of Haslund's character - who is, by the way, christened Harald, an old royal name which immediately indicates that he is the supreme head of the family - always calls her Lillemor. In Norwegian this means something like "little girl", indicating a small and helpless creature, unable to take care of herself and with no real importance. So there she is, safely put in her place.

[13] My translation of "Men hun var så ærgjerrig, så forferdelig ærgjerrig." The Norwegian quotation is derived from Mord etter alfabetet (Christie 1964, 159).

[14] My translation. Ibid.

[15] Just a Small Breakdown. 
Pet names and nicknames are often used as a means to control, manipulate or degrade other people. In literature it can often be observed that a character's newly gained understanding of his or her own self or a strengthened feeling of identity makes them throw away a despised pet name or a pseudonym used as a mask or a smokescreen, and start using their Christian name instead. The above mentioned Lillemor is one example of this - she experiences a personal growth and reclaims the right to be Beatrice again. But the loss of a pet name can also lead to a feeling of lost identity - you lose the part of yourself that was expressed through the pet name, or the part of your life symbolized by the pet name. In a novella by Sigrid Undset, Fru Hjelde ${ }^{16}$ (1917), the female protagonist Uni reacts with melancholy and sadness when her husband transfers the pet name he has once given her, Hvitepus, to their eldest daughter. ${ }^{17}$ Because of this, she feels that their relationship has lost its warmth and closeness.

\section{[7] CONCLUSION}

The examples I have given here show that the bonds between names and identity are as close in literature as in real life - maybe even closer. Names and naming are some of the most significant parts of the strategy used by an author to present a literary character as a particular individual. Literary onomastics - the investigation of names in literature - is still a young discipline, but more and more literary critics are becoming aware of the importance of names in the interpretation of novels and authorships. Roland Barthes was originally of the opinion that names were empty labels with no inherent meaning at all, but little by little he changed his view and finally became excited by the role of proper names during the process of literary creation. He claims that the personal names in a literary work have an inestimable value for the creativity of the author, and he even went as far as to maintain that Marcel Proust would never have been able to write In Search of Lost Time had he not found the right names to make the identity of the characters blossom fully in his fantasy. ${ }^{18}$ It is a bold statement, and it is not easy to evaluate its veracity. But there is no doubt that the link between names and identity can give new insights into the development of the personality and important aspects of individual identity, even in literature.

\section{REFERENCES}

Allport, G.W. 1961. Pattern and growth in personality. New York: Holt, Rinehart and Winston.

[16] Mrs. Hjelde. The overarching novel itself is known in English translation as Images in a Mirror (Splinten $i$ troldspeilet), trans. by Arthur G. Chater (London: Cassell, 1938). Its first translation only included Fru Hjelde, not Fru Waage.

[17] Chater translates Hvitepus as e.g. 'little puss' and 'Puss'.

[18] (Barthes 1994, 67). 
Barthes, R. 1994. Proust og navnene. In I tegnets tid. Utvalgte artikler og essays, 63-71. Oslo: Pax.

Christie, A. 1936. A.B.C. Murders. London: Collins.

Christie, A. 1964. Mord etter alfabetet. Oslo: Aschehoug.

Dion, K. L. 1983. Names, Identity, and Self. Names 31,4. 245-257.

Ekelöf, G. 1941. Färjesång. Stockholm: Bonniers.

Grimaud, M.1989. Onomastics and the Study of Literature. Yearbook of Comparative and General Literature 38. 16-35.

Gripe, M. 1967. Landet utanför. Stockholm: Bonniers.

Hamon, P. 1992. On the Major Features of Realist Dicourse. In Furst, L.R. (ed.): Realism, 166-85. London: Longman.

Hamsun, T. (ed.). 1988. Knut hamsuns brev til marie. Oslo: Aschehoug.

Haslund, E. 1975. Bare et lite sammenbrudd. Oslo: Aschehoug.

Larsen, L.J. 2001. Mønsteret og meningen. agnar mykles romaner om ask burlefot. Trondheim: Institutt for nordistikk og litteraturvitenskap, Det historisk-filosofiske fakultetet, Norges teknisk-naturvitenskapelige universitet. Unpublished doctoral thesis.

Mykle, A. 1956. Sangen om den røde rubin. Oslo: Gyldendal.

Stemshaug, O. 1981. Namnebruken i Johan Falkbergets diktning. In Stemshaug, $O$. (ed.): Norske personnamnstudiar, 10-43. Oslo: Samlaget.

AUTHOR CONTACT INFORMATION

Benedicta Windt-Val

Fornes

N-8484 Risøyhamn

Norway

benwin1@nordlysnett.no 